\title{
A NEW VARIETY OF COREOPSIS MUTICA (ASTERACEAE) FROM WESTERN OAXACA
}

\author{
B.L. Turner \\ Department of Botany, University of Texas, Austin, Texas 78713 U.S.A.
}

\begin{abstract}
A new variety of Coreopsis mutica, $\boldsymbol{C}$. mutica var. miahuatlana B.L. Turner, is described from Mpio. Miahuatlán, Oaxaca, México. It is a shrub or small tree $2.0-5.0 \mathrm{~m}$ high and relates closely to var. subvillosa. The distinctions between these two varieties are discussed.
\end{abstract}

KEY WORDS: Asteraceae, Coreopsis, México, Oaxaca, systematics

Crawford (1970) provided an excellent study of Coreopsis mutica A. DC. in which seven regional varieties were recognized. Crawford (1981) added an additional varietal element to the group. Turner (1992) reviewed the taxonomy of the complex, reducing some of Crawford's taxa to synonymy, but added a newly described taxon, C. mutica var. guerreroana B.L. Turner, maintaining seven varietal taxa, all of these keyed and mapped.

I describe herein a new variety, Coreopsis mutica var. miahuatlana from westcentral Oaxaca, where it is seemingly confined to Mpio. Miahuatlán. In my revised key to the group (Turner 1992) the present taxon will key to var. carnosifolia D. Crawford, but differs from the latter in having much larger, less succulent leaves which dry dark (vs. semisucculent smaller leaves which dry pale green). In addition the capitulescence is broader and more numerous-headed. The closest relationship of var. miahuatlana appears to be with var. subvillosa D. Crawford; indeed, occasional specimens of the former take on characters of the latter (e.g., Hinton 26603, in pubescence; and Hinton 26735, in its lobed leaves). In my treatment of 1992 I included at least one collection of var. miahuatlana (Turner $80 A-9$ [TEX], cited below) in my concept of var. subvillosa, taking this at the time to be an intermediate between var. subvillosa and var. carnosifolia. I would now call this collection an intergradant between the latter and var. miahuatlana. 


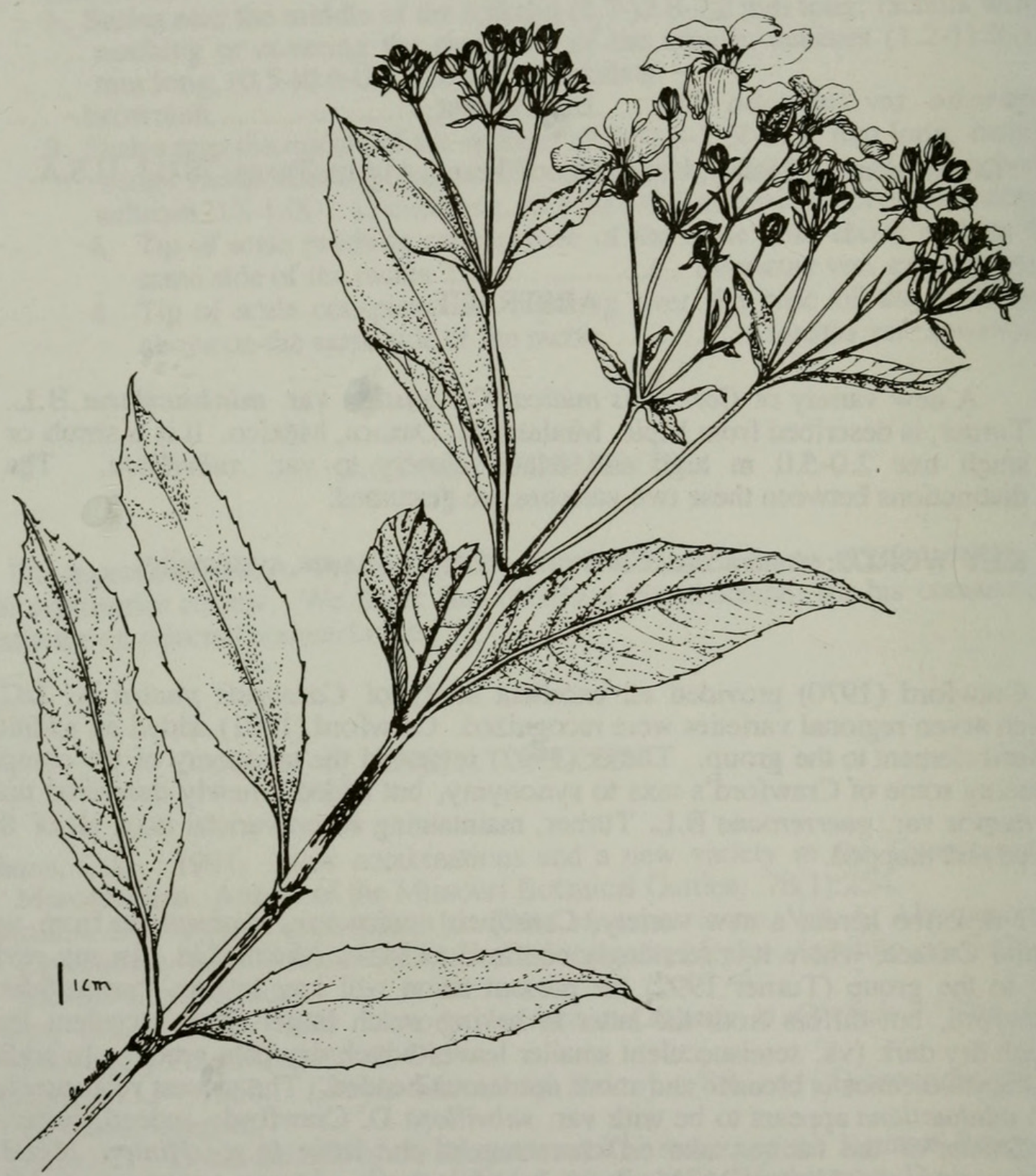

Figure 1. Coreopsis mutica var. miahuatlana (from holotype). 
COREOPSIS MUTICA A. DC. var. MIAHUATLANA B.L. Turner, var. nov. Figure 1. TYPE: MEXICO. Oaxaca: Mpio. Miahuatlán, Santo Domingo, 2240 m, IRF Río Magdalena, tree 5 m, common, 4 Aug 1996, Hinton, et al. 26724 (HOLOTYPE: TEX!).

Similis Coreopsi muticae (Coreopsis mutica) A. DC. var. subvillosa D. Crawford, sed plantae majores sunt, foliis primariis majoribus, plerumque 10$13 \mathrm{~cm}$ longis (vice 3-9 cm longis), denigratis ubi siccis, glabris aut paene glabris ubique, et foliis immaturis subvillosis.

Shrub or small tree 2.0-5.0 m high. Stems and foliage glabrous throughout or nearly so, but juvenile leaves sometimes moderately to sparsely pubescent. Midstem (primary) leaves mostly $10-15 \mathrm{~cm}$ long, $2.5-4.5 \mathrm{~cm}$ wide, drying dark green or blackish, the margins serrulate. Heads numerous, arranged in broad rounded terminal corymbose panicles $5-10 \mathrm{~cm}$ high, $10-16 \mathrm{~cm}$ across. Primary peduncles $1-2 \mathrm{~cm}$ long, the ultimate peduncles mostly $1-3 \mathrm{~cm}$ long. Involucres narrowly campanulate, 7-9 mm high, 5-6 mm wide (pressed); outer bracts 4-5, oblanceolate, 3-nervate, mostly 4-7 mm long; inner bracts ca. 8, subscarious, free to base or nearly so. Ray florets mostly 5; ligules yellow, $1-2 \mathrm{~cm}$ long, $0.6-1.0 \mathrm{~cm}$ wide. Disk florets $18-25$ (estimated); corollas yellow. Anther sacs purple. Achenes narrowly ellipsoidal, ca. $8 \mathrm{~mm}$ long, 2 mm wide.

ADDITIONAL SPECIMENS EXAMINED (all from Mpio. Miahuatlán): Quiexobra, $2300 \mathrm{~m}$, deep rocky gorge, 14 Oct 1995, Hinton, et al. 26122 (TEX); Xianaguilla, 2325 m, 22 Oct 1995, Hinton, et al. 26327 (TEX); above Xianaguilla, 2550 m, 23 Oct 1995, Hinton, et al. 26357 (TEX); San Francisco Ozolotepec, 2815 $\mathrm{m}, 8$ Aug 1996, Hinton, et al. 26839 (TEX); $35 \mathrm{mi}$. SE of Ejutla, road to Puerto Angel, 22 Aug 1980, Turner 80A-9 (TEX).

All of the above collections are said to be common shrubs or trees, varying from 2.0-5.0 m high and collected between $2240-2815 \mathrm{~m}$ in pine-oak forests. The closest relative of var. miahuatlana is the allopatric var. subvillosa, which is consistently described as a suffruticose herb or shrub 0.5-2.0 m high, occurring in pine-oak forests from $2100-2500 \mathrm{~m}$.

In Crawford's (1970) treatment of the Coreopsis mutica complex, var. miahuatlana, because of its 5-6 ray florets, will key to or near C. mutica var. microcephala D. Crawford, a taxon with smaller heads occurring to the east of the Isthmus of Tehuantepec. I gave this identification to the first collections of the present plants obtained from the Miahuatlán area by James Hinton, but the fine series of subsequent collections obtained by this ardent field botanist has lead me to conclude that the taxon concerned is deserving of formal recognition.

\section{ACKNOWLEDGMENTS}

I am grateful to Gayle Turner for the Latin diagnosis, and to her and Justin Williams for reviewing the manuscript. Ms. Maria Thompson provided the
illustration. 


\section{LITERATURE CITED}

Crawford, D. 1970. Systematic studies on Mexican Coreopsis (Compositae), Coreopsis mutica: flavonoid chemistry, chromosome numbers, morphology, and hybridization. Brittonia 22:93-111.

1981. A new variety of Coreopsis mutica (Compositae) from Mexico. Brittonia 33:547-554.

Turner, B.L. 1992. Coreopsis mutica var. guerreroana (Asteraceae), a new taxon from México. Phytologia 73:7-13. 


\section{$2 \mathrm{BHL}$ Biodiversity Heritage Library}

Turner, B. L. 1996. "A new variety of Coreopsis mutica (Asteraceae) from western Oaxaca." Phytologia 80, 291-294. https://doi.org/10.5962/bhl.part.15541.

View This Item Online: https://www.biodiversitylibrary.org/item/47108

DOI: https://doi.org/10.5962/bhl.part.15541

Permalink: https://www.biodiversitylibrary.org/partpdf/15541

\section{Holding Institution}

New York Botanical Garden, LuEsther T. Mertz Library

\section{Sponsored by}

The LuEsther T Mertz Library, the New York Botanical Garden

\section{Copyright \& Reuse}

Copyright Status: In copyright. Digitized with the permission of the rights holder.

Rights Holder: Phytologia

License: http://creativecommons.org/licenses/by-nc-sa/3.0/

Rights: https://biodiversitylibrary.org/permissions

This document was created from content at the Biodiversity Heritage Library, the world's largest open access digital library for biodiversity literature and archives. Visit BHL at https://www.biodiversitylibrary.org. 